Article

\title{
Effect of Thermo-Mechanical Processing on the Corrosion Behavior of Fe-30Mn-5Al-0.5C TWIP Steel
}

\author{
Ulises Martin (D), Jacob Ress, Juan Bosch and David M. Bastidas *
}

National Center for Education and Research on Corrosion and Materials Performance, NCERCAMP-UA, Department of Chemical, Biomolecular, and Corrosion Engineering, The University of Akron, 302 E Buchtel Ave, Akron, OH 44325-3906, USA; um11@zips.uakron.edu (U.M.); jtr45@zips.uakron.edu (J.R.); jb394@zips.uakron.edu (J.B.)

* Correspondence: dbastidas@uakron.edu; Tel.: +1-330-972-2968

Received: 27 November 2020; Accepted: 17 December 2020; Published: 19 December 2020

\begin{abstract}
Electrochemical corrosion of thermo-mechanically processed (TMP) and recrystallized $\mathrm{Fe}-30 \mathrm{Mn}-5 \mathrm{Al}-0.5 \mathrm{C}$ twinning-induced plasticity (TWIP) steels containing $30 \mathrm{wt} . \% \mathrm{Mn}$ was studied in a $1.0 \mathrm{wt} . \% \mathrm{NaCl}$ electrolyte solution. The alkaline nature of the corrosion products containing manganese oxide (MnO) increases the dissolution kinetics of the TWIP steel in acid media, obtaining $\mathrm{Mn}^{2+}$ cations in solution, and producing the hydrogen evolution reaction (HER). X-ray photoelectron spectroscopy (XPS) surface analysis revealed an increased $\mathrm{Al}_{2} \mathrm{O}_{3}$ content of $91 \%$ in the passive layer of the recrystallized TWIP steel specimen, while in contrast only a $43 \% \mathrm{Al}_{2} \mathrm{O}_{3}$ was found on the TMP specimen. Additionally, the chemical composition of the surface oxide layer as well as the TWIP alloy microstructure was analyzed by optical microscopy (OM) and scanning electron microscopy (SEM). The results indicate an enhanced corrosion attack for the TMP high-Mn TWIP steel.
\end{abstract}

Keywords: thermo-mechanical processing; dislocation glide; TWIP steel; corrosion; cyclic potentiodynamic polarization; XPS

\section{Introduction}

In order to stabilize the austenitic phase in a twinning-induced plasticity (TWIP) steel at room temperature (RT), a Mn content higher than $27 \mathrm{wt} . \%$ is required [1-4]. The obtention of a stable carbidefree fully austenitic microstructure on TWIP steel with manganese contents below $25 \mathrm{wt} . \% \mathrm{Mn}$, requires a low-carbon content $(<0.6 \mathrm{wt} . \% \mathrm{C})$, carbon is an interstitial element which acts as an austenite stabilizer [5]. However, increased $\mathrm{C}$ content promote the formation of carbides $\left(\mathrm{Fe}_{3} \mathrm{C}\right.$ and $\left.\mathrm{Mn}_{3} \mathrm{C}\right)$ [6-8]. The main alloying element in TWIP steels is considered to be Mn due to its crucial roles in preserving the austenitic structure as well as controlling the stacking fault energy (SFE) of the ternary $\mathrm{Fe}-\mathrm{Mn}-\mathrm{Al}$ alloy $[9,10]$. Depending on the magnitude of the SFE, different phase transformation processes can be promoted. For instance, martensitic transformation is favored for SFE values below $12 \mathrm{~mJ} / \mathrm{m}^{2}$; predominant twinning and gliding dislocation mechanisms are found between 12 and $35 \mathrm{~mJ} / \mathrm{m}^{2}$; and above $35 \mathrm{~mJ} / \mathrm{m}^{2}$ dislocation glide is the dominant deformation mechanism [11-13].

With superior formability and excellent tensile strength, high-Mn TWIP steel offers improved mechanical properties through strain hardening. Consequently, the use of high-Mn TWIP steel is of paramount important to decrease structural components' weight, while improving the press forming behavior. These benefits are highly sought in the automotive industry for decreasing fuel consumption and reducing greenhouse gas emissions [14,15]. High-Mn TWIP steels (15-30 wt.\% Mn) present a wide range of applications, for instance, structural elements in the automotive industry. This is due to the 
high tensile strength (above $1 \mathrm{GPa}$ ) as well as a great tensile-strength-to-ductility ratio. Furthermore, TWIP steels present higher energy absorption properties $(>55 \mathrm{~kJ} / \mathrm{kg}$ ), as compared to other advance high-strength steel (AHSS) grades such as transformation induced plasticity (TRIP) steel TRIP700, and also the dual phase (DP) steel DP600 [16-19]. Due to their impact resistance, effectiveness, and low environmental impact, TWIP steels have become of major interest in the automotive industry. However, the corrosion of TWIP steels presents a significant hurdle for their practical use [20-22].

It has been reported that cold plasticity deformation of high-Mn TWIP steels enhances the susceptibility of corrosion [23-25]. Furthermore, the higher Mn content promotes the electrochemical activity of the alloy in chloride and acidic solutions [26]. An increase in the electrochemical dissolution kinetics of TWIP steel has been observed in acid media due to the presence of alkaline Mn oxide (MnO) in the corrosion products. This increased anodic dissolution is attributed to the presence of $\mathrm{Mn}^{2+}$ cations in solution, and the subsequent hydrogen evolution reaction (HER) on the cathodic half-cell electrochemical reaction [27].

Increased $\mathrm{Al}$ content in high-Mn TWIP steel has been shown to improve corrosion performance, while additions of $\mathrm{Mn}$ reduce the corrosion resistance [28,29]. Despite the more active standard reversible potential of $\mathrm{Al}$ than that of $\mathrm{Mn}, E_{\mathrm{Al} 3+/ \mathrm{Al}}=-1.66 \mathrm{~V}_{\mathrm{SHE}}$ and $E_{\mathrm{Mn} 2+/ \mathrm{Mn}}=-1.18 \mathrm{~V}_{\mathrm{SHE}}$, respectively, where SHE is standard hydrogen electrode, the higher Mn content governs the anodic dissolution reaction on TWIP steels [30]. Al has been found to impart corrosion protection on TWIP steels by the formation of a stable aluminum oxide $\left(\mathrm{Al}_{2} \mathrm{O}_{3}\right)$ passive surface layer [31]. Moreover, $\mathrm{Al}$ addition decreases the corrosion current density $\left(i_{\text {corr }}\right)$ while increasing the corrosion potential ( $\left.E_{\text {corr }}\right)$ towards nobler values, whereas increased Mn content produces the opposite effect [32]. Lastly, the corrosion resistance was shown experimentally to increase with $\mathrm{Al}$ additions and decrease with $\mathrm{Mn}$ additions by polarization curves of $\mathrm{Fe}-\mathrm{Mn}-\mathrm{Al}$ alloys in sodium hydroxide ( $\mathrm{NaOH}$ ) solution [26].

This work aims to reveal the influence of the thermo-mechanical process on the corrosion performance of high-Mn TWIP steels. To better understand the correlation between microstructure and corrosion mechanisms, a recrystallized high-Mn TWIP steel was also studied. Electrochemical corrosion behavior was investigated in a $1.0 \mathrm{wt} . \% \mathrm{NaCl}$ solution and the corrosion products, alloy microstructure and surface composition and morphology were studied by electrochemical methods and surface analysis techniques.

\section{Materials and Methods}

The elemental composition of as-cast high-Mn TWIP steel ingots containing $30 \mathrm{wt} . \% \mathrm{Mn}, 5 \mathrm{wt} . \%$ $\mathrm{Al}, 0.5 \mathrm{wt} . \% \mathrm{C}, 0.01 \mathrm{wt} . \% \mathrm{~S},<0.01 \mathrm{wt} . \% \mathrm{P}$, and balance Fe, was determined by X-ray fluorescence (XRF) using a S8 Tiger (Bruker, Middleton, WI, USA) wavelength dispersive spectrometer. Specimens were obtained from ingots of TWIP steel prepared in a high temperature furnace using an alumina crucible and argon as a protective gas environment. The main constituents of the alloy are Fe and Mn, while $\mathrm{Al}$ and $C$ are the main alloying elements. Figure 1 shows a typical microstructure of as-cast specimens with dendrites and interdendritic spaces of a solidification microstructure.

The ingots were subjected to a thermo-mechanical processing (TMP), which consists of a hot-rolling process at $1100{ }^{\circ} \mathrm{C}$. Strips with a final thickness of $2.5 \mathrm{~mm}$ were obtained. Subsequently, the strips were subjected to a cold-rolling process to decrease the thickness to $1.5 \mathrm{~mm}$. Followed by recrystallization at $900{ }^{\circ} \mathrm{C}$ for $30 \mathrm{~min}$, obtaining a microstructure characterized by equiaxial grains of $\sim 20 \mu \mathrm{m}$ in diameter.

For the cyclic potentiodynamic polarization (CPP) test, the specimens were mounted in epoxy resin and the surface was prepared with silicon carbide $(\mathrm{SiC})$ paper, grinding up to 1200 grade, then cleaned with ethanol and deionized water followed by air-drying. Specimens were immediately tested after sample preparation. Furthermore, a protective lacquer was used to prevent crevice corrosion in the resin/alloy interface. The electrolyte used was a deaerated $1 \mathrm{wt} . \% \mathrm{NaCl}$ solution with $30 \mathrm{~min}$ of nitrogen bubbling to avoid oxygen depolarization by oxygen reduction. A 30 min open circuit potential (OCP) monitoring was performed prior to testing until steady-state was reached. 


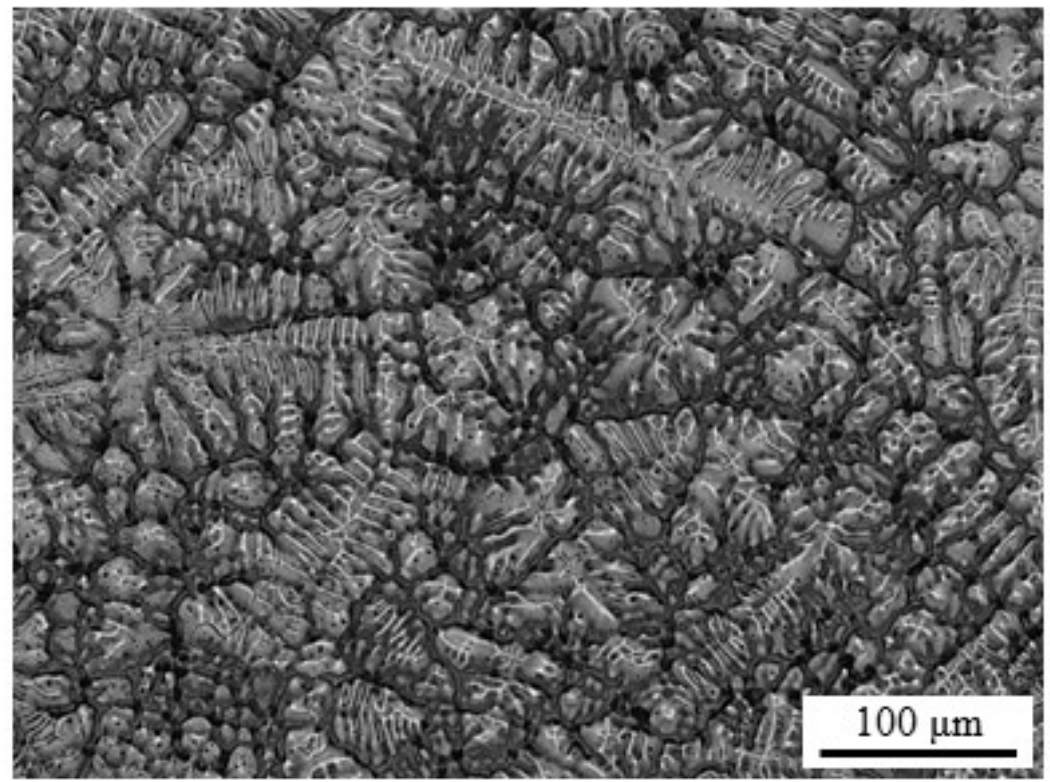

Figure 1. Micrograph of an as-cast Fe-30Mn-5Al-0.5C twinning-induced plasticity (TWIP) steel specimen.

CPP tests were performed starting from a potential of $-0.03 \mathrm{~V}_{\mathrm{OCP}}$ and scanned anodically until the current density limit of $1.0 \times 10^{-3} \mathrm{~A} / \mathrm{cm}^{2}$ was achieved, after that, the scan was reversed in the cathodic direction and the scan rate was $0.1667 \mathrm{mV} / \mathrm{s}$ according to ASTM G61-86 standard [33]. All experiments were performed at room temperature $\left(\sim 25^{\circ} \mathrm{C}\right)$ and in triplicate, ensuring reproducibility. The polarization tests were performed using a three-electrode electrochemical cell with the TWIP specimen acting as the working electrode, a platinum mesh with a large surface area as the counter electrode, and a saturated calomel (SCE) reference electrode. The CPP tests were performed using a potentiostat/galvanostat Gamry Reference 600 (Gamry Instruments, Warminster, PA, USA).

Specimens for metallographic analysis were prepared by grinding to 2000 grit $\mathrm{SiC}$ paper and polishing to a mirror finish using $500 \mathrm{~nm}$ non-crystalline colloidal silica. Etching of the polish specimens was done by immersion in Nital solution (10 wt. $\% \mathrm{HNO}_{3}$ in ethanol) for $30 \mathrm{~s}$. The microstructure was characterized by optical microscopy (OM) Nikon Eclipse MA 100 (Nikon Metrology Inc., Brighton, MI, USA), scanning electron microscopy (SEM) Hitachi-TM3030 (Hitachi High-Tech America Inc, Schaumburg, IL, USA), and infinite focus microscopy (IFM) in an Alicona infinite focus G5 microscope (Bruker, Itasca, IL, USA).

X-ray photoelectron spectroscopy (XPS) was conducted after a passive layer was generated by potentiostatic polarization for $1 \mathrm{~h}$ at $-0.750 \mathrm{~V}_{\mathrm{SCE}}$ in $1.0 \mathrm{wt} . \% \mathrm{NaCl}$ solution and under deareated conditions. This passive layer formation procedure has been shown in previous works to alter the surface layer [28,34]. In order to minimize surface contamination, the samples were introduced in a nitrogen saturated glove bag to eliminate oxygen contamination immediately after CPP tests.

XPS surface analysis was conducted using a PHI 5000 VersaProbe II (Physical Electronics Inc., Chanhassen, MN, USA) spectrophotometer with an $\mathrm{Al} \mathrm{K} \alpha$ source $(h \mathrm{v}=1486.6 \mathrm{eV})$, a working residual pressure below $10^{-9}$ torr, a high-voltage excitation of $15 \mathrm{kV}$, a power of $25 \mathrm{~W}$ and a take-off angle of $45^{\circ}$ with respect to the sample surface. The high resolution XPS used a CLAM2 hemispherical electron analyzer with a non-monochromatic $\mathrm{Mg} \mathrm{K}_{\alpha}$ X-ray source operated at $300 \mathrm{~W}$, with a pass energy of $23.5 \mathrm{eV}$ and at energy step size of $0.2 \mathrm{eV} / \mathrm{step}$. The Fe 2p $3 / 2, \mathrm{Al} 2 \mathrm{p}, \mathrm{Mn} 2 \mathrm{p}, \mathrm{O} 1 \mathrm{~s}$, and $\mathrm{C} 1 \mathrm{~s}$ areas were analyzed. The calibration was done on Ag standard substrate, using independent measurements for the Ag $3 d_{5 / 2}$ peak $(368.3 \mathrm{eV})$. A Gaussian-Lorentzian mixed function was used to fit the data, after a Shirley background subtraction [28]. The binding energy reference used was adventitious $C$, with $285.0 \mathrm{eV}$ for $\mathrm{C}$ 1s peak. 


\section{Results and Discussion}

OM images of TMP and recrystallized TWIP steel samples are presented in Figure 2. Figure 2a shows the TMP specimen microstructure with oriented grains as a consequence of deformation during the hot-rolling process. In contrast, Figure $2 \mathrm{~b}$ includes the recrystallized TWIP steel specimen showing a homogeneous $\gamma$-austenite monophasic microstructure with equiaxial grains and the presence of annealing twin formation on individual grains during recrystallization and grain growth processes. In addition to the annealing twin formation, an increase in the grain size of the recrystallized TWIP samples is seen, similar to what it can be seen in the literature at that temperature range $[35,36]$. While the recrystallization decreases the dislocation density, the twin density is not affected as much, most of the twins remaining previously formed [35].
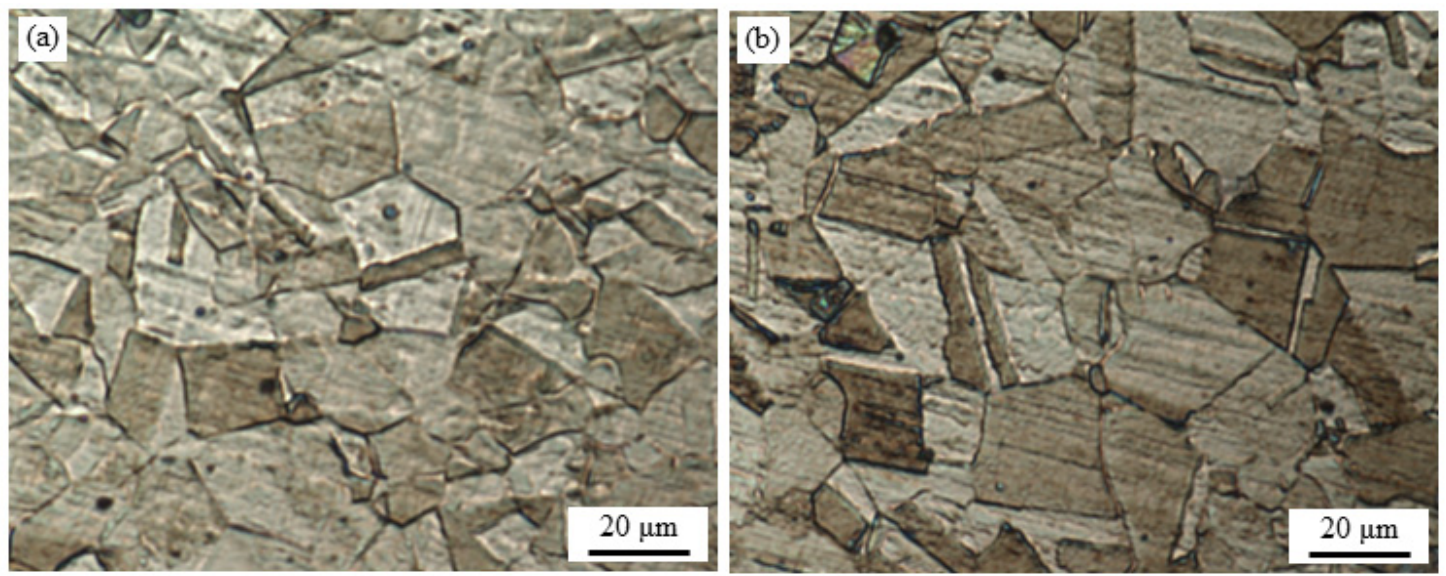

Figure 2. Optical microscopy (OM) micrographs: (a) thermo-mechanical processed (TMP), and (b) recrystallized $\mathrm{Fe}-30 \mathrm{Mn}-5 \mathrm{Al}-0.5 \mathrm{C}$ TWIP steel specimens.

To further study the microstructure of the recrystallized specimen, SEM micrographs were taken. Figure 3 shows a typical austenitic monophasic microstructure for the recrystallized specimens, confirming the homogeneous $\gamma$-austenite monophasic microstructure with equiaxial grains and the presence of annealing twin formation on individual grains.

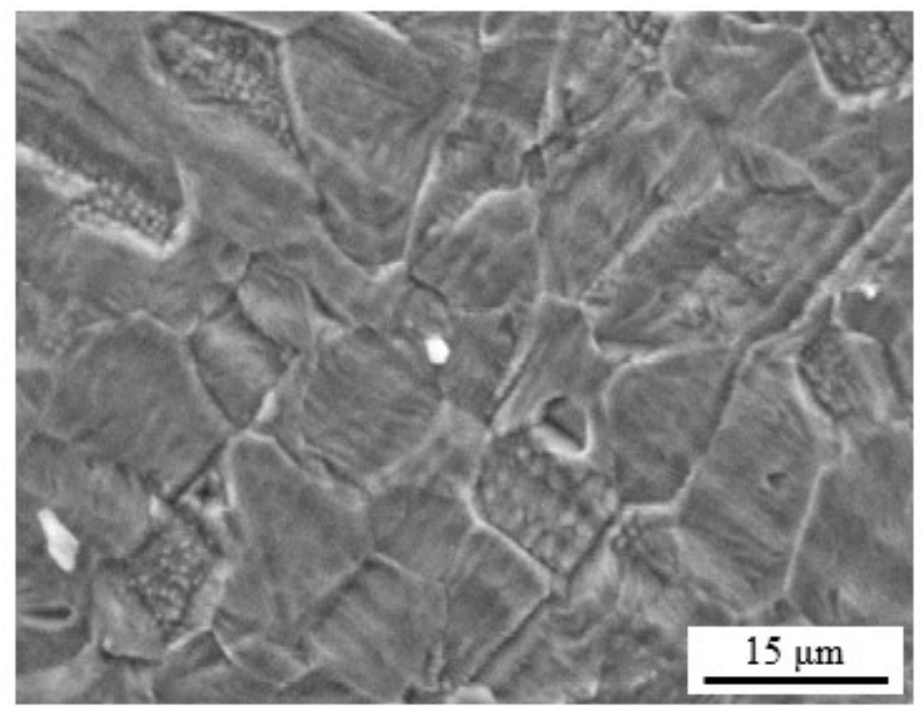

Figure 3. SEM micrograph of the recrystallized Fe-30Mn-5Al-0.5C TWIP specimens. 
CPP curves for TMP and recrystallized TWIP steel specimens immersed in the deaerated $1.0 \mathrm{wt} . \%$ $\mathrm{NaCl}$ solution at RT are presented in Figure 4 to compare the electrochemical behavior. A passive-like behavior can be observed in both samples. The passive current density $\left(i_{\text {pass }}\right)$, which indicates the passivity plateau, can be observed with values around $18.03 \mu \mathrm{A} / \mathrm{cm}^{2}$ for both the TMP and recrystallized specimens. Furthermore, an increase in the pitting potential $\left(E_{\text {pit }}\right)$ which is defined by an abrupt increase in the current density, can be observed. It should be noted that in the absence of oxygen in the deaerated $1.0 \mathrm{wt} . \% \mathrm{NaCl}$ solution, the primary cathodic reaction is HER. If an activation-controlled kinetics is assumed, the behavior can be explained via an increase in the reversible potential for the $\operatorname{HER}\left(E_{\mathrm{rev}, \mathrm{H}}\right)$ due to a $\mathrm{pH}$ decrease in the solution as well as an increase in the catalytic properties of the surfaces towards the HER. Differences can be observed between the TMP and recrystallized specimens. The TMP TWIP steel showed higher values for the cathodic current density than the recrystallized specimen.

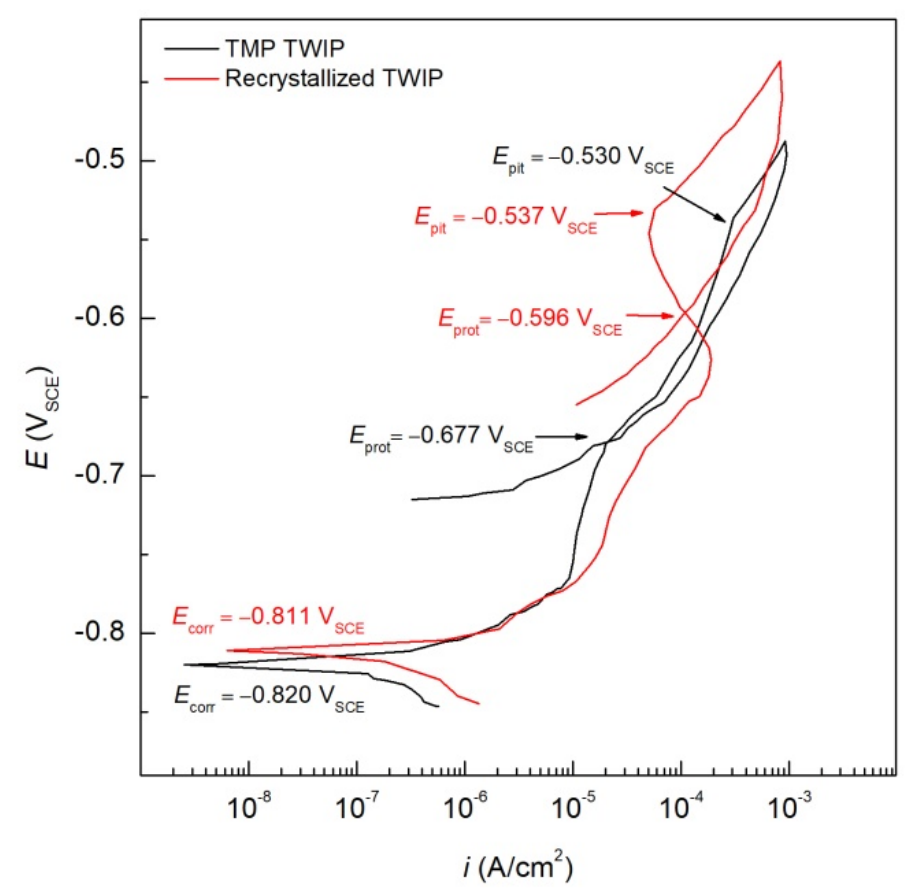

Figure 4. Cyclic potentiodynamic polarization CPP of TMP and recrystallized TWIP steels in deaerated 1.0 wt. $\% \mathrm{NaCl}$ solution.

Differences can also be observed in the anodic kinetics. For the TMP TWIP specimen, a small passivity plateau was drawn with an $i_{\text {pass }}$ value of $9.44 \mu \mathrm{A} / \mathrm{cm}^{2}$, this low $i_{\text {pass }}$ may be related to the protective properties of the thin and stable $\mathrm{Al}$ oxide layer formed. This $\mathrm{Al}$ imparts passivity via the formation of an $\mathrm{Al}_{2} \mathrm{O}_{3}$ layer [28]. Comparatively, $\mathrm{Al}$ displays a more active behavior than $\mathrm{Mn}$, hindering the electrode reaction [28]. It should be noted that $\mathrm{Al}$ content not only increases the SFE, but also stabilizes the $\gamma$-austenite against phase transformation [6,37]. After reaching the anodic current density limit $\left(1.0 \times 10^{-3} \mathrm{~A} / \mathrm{cm}^{2}\right)$, the polarization was reversed in the cathodic direction in order to assess the repassivation behavior of the high-Mn TWIP steels. This repassivation is reached once the recorded current density intersects the forward scan line, defining the protection potential $\left(E_{\text {prot }}\right)$. This behavior was showed in both TWIP steel alloys studied after a positive hysteresis loop was observed. The larger this loop, the higher the resistance to repassivation of the alloy and, thus, greater susceptibility to local corrosion is observed.

Table 1 summarizes the values for the $E_{\text {corr }}, E_{\text {pit }}, i_{\text {pass }}, E_{\text {prot}}$, and $\Delta E=E_{\text {pit }}-E_{\text {prot }}$ electrochemical parameters obtained from the CPP curves in Figure 4. More noble $E_{\text {corr }}$ values were exhibited by the recrystallized specimens than by the TMP specimens, with a small difference of $0.09 \mathrm{~V}$ for the recrystallized 
specimen. Similarly, more positive $E_{\text {pit }}$ values were shown for the recrystallized than for TMP specimens, thus indicating a higher resistance to pitting corrosion, which may be interpreted as a less protective passive layer formed on the TMP specimen than that of the recrystallized specimen. In general, both type of specimens (TMP and recrystallized) exhibited the ability to repassivate. The hysteresis loop $(\Delta E)$, defined by $\Delta E=E_{\text {pit }}-E_{\text {prot }}$, allows the evaluation of the susceptibility to localized corrosion [35]. Thus, smaller values of $\Delta E$ mean higher resistance to pitting. Though, the differences of $\Delta E$ for the TMP and recrystallized specimen were found to be 0.147 and $0.059 \mathrm{~V}_{\mathrm{SCE}}$, respectively.

Table 1. Electrochemical parameters obtained from the CPP tests of TMP and recrystallized TWIP steels in deaerated 1.0 wt.\% NaCl solution (see Figure 4).

\begin{tabular}{cccccc}
\hline Sample & $\begin{array}{c}E_{\text {corr }} \\
\left(\mathbf{V}_{\text {SCE }}\right)\end{array}$ & $\begin{array}{c}E_{\text {pit }} \\
\left(\mathbf{V}_{\text {SCE }}\right)\end{array}$ & $\begin{array}{c}E_{\text {prot }} \\
\left(\mathbf{V}_{\text {SCE }}\right)\end{array}$ & $\begin{array}{c}i_{\text {pass }} \\
\left(\boldsymbol{\mu} \mathbf{A} / \mathbf{c m}^{2}\right)\end{array}$ & $\begin{array}{c}\Delta E \\
\left(\mathbf{V}_{\text {SCE }}\right)\end{array}$ \\
\hline TMP TWIP & $-0.820 \pm 0.052$ & $-0.677 \pm 0.056$ & $-0.530 \pm 0.042$ & $9.44 \pm 0.61$ & $0.147 \pm 0.011$ \\
Recrystallized TWIP & $-0.811 \pm 0.065$ & $-0.596 \pm 0.031$ & $-0.537 \pm 0.054$ & $18.03 \pm 0.97$ & $0.059 \pm 0.013$ \\
\hline
\end{tabular}

Figure 5 shows the IFM images of TMP TWIP steel (see Figure $5 a, b$ ) and recrystallized TWIP steel specimens (see Figure $5 c, d$ ) both after the CPP test in deaerated $1.0 \mathrm{wt} . \% \mathrm{NaCl}$ solution. Figure $5 \mathrm{a}, \mathrm{b}$ reveal a higher pit density for the TMP TWIP steel compared to the recrystallized TWIP steel sample [29]. The recrystallization of the grains of TMP TWIP, seen in Figure 3, decreased the locations for pits to nucleate, as well as the recrystallization made for a greater alumina layer which enhanced the corrosion protection of the samples (see Figure $5 \mathrm{c}, \mathrm{d}$ ). Despite the addition of the recrystallization process, a similar pit depth of $\sim 6 \mu \mathrm{m}$ was found on both specimens, while wider pits were shown on the TMP TWIP specimen, therefore a small pit aspect ratio is depicted for the recrystallized TWIP steel specimen.

(a)

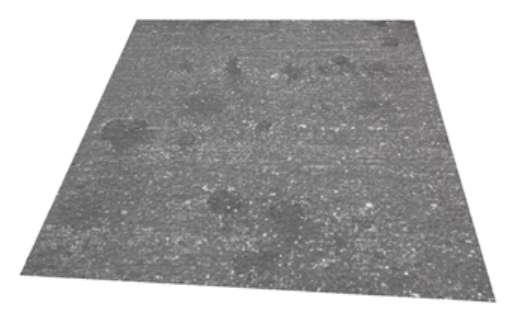

(c)

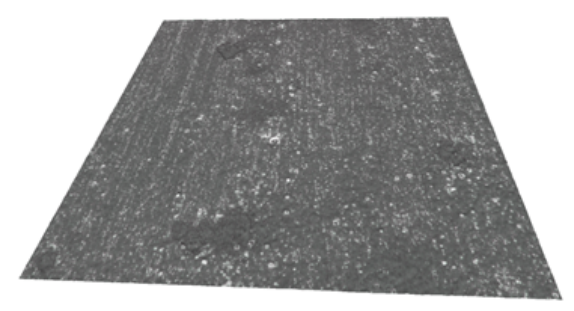

(b)

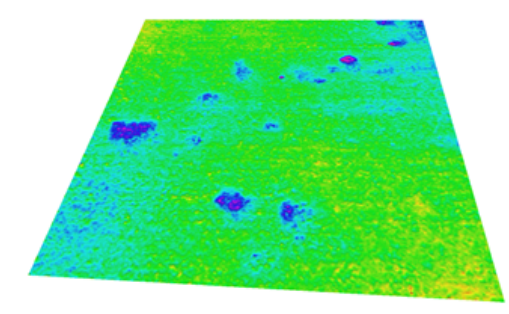

(d)

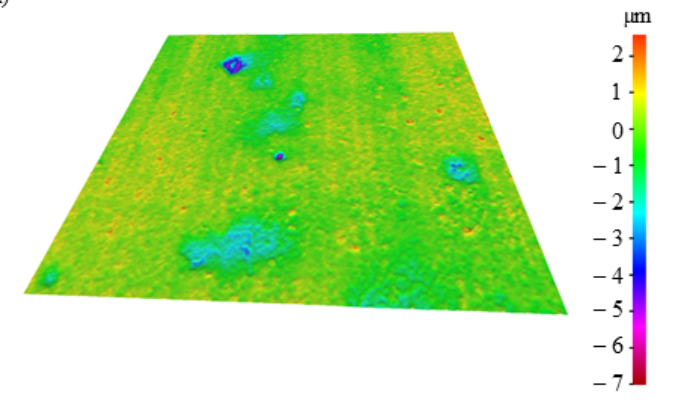

Figure 5. Infinite focus microscopy (IFM) images after CPP in deaerated $1.0 \mathrm{wt} . \% \mathrm{NaCl}$ : (a) TMP TWIP sample, (b) TMP TWIP topography, (c) recrystallized TWIP, and (d) recrystallized TWIP topography.

The high resolution XPS spectra of the TMP TWIP steel is presented in Figures 6 and 7 for Fe $2 p_{3 / 2}$ and $\mathrm{Al} 2 \mathrm{p}$, respectively. Four peaks were assigned to iron, metallic $\mathrm{Fe}$ at $707.2 \mathrm{eV}, \mathrm{Fe}^{2+}$ oxide ( $\mathrm{FeO}$ ) at $709.2 \mathrm{eV}, \mathrm{Fe}^{3+}$ oxide $\left(\mathrm{Fe}_{2} \mathrm{O}_{3}\right)$ at $711.2 \mathrm{eV}$, and $\mathrm{Fe}^{3+}$ oxyhydroxide $(\alpha-, \beta-$ or $\gamma-\mathrm{FeOOH})$ at $713.3 \mathrm{eV}$ 
as observed in Figure 6 [34,38,39]. Figure 7 shows high resolution XPS spectrum of TMP TWIP steel specimen for $\mathrm{Al} 2 \mathrm{p}$ containing two peaks assigned to metallic $\mathrm{Al}$ at $72.0 \mathrm{eV}$ and $\mathrm{Al}^{3+}$ oxide $\left(\mathrm{Al}_{2} \mathrm{O}_{3}\right)$ at $74.5 \mathrm{eV}$. This $\mathrm{Al}_{2} \mathrm{O}_{3}$ layer present in the surface is related to the passive behavior observed in the CPP tests performed. High resolution XPS spectra for the recrystallized TWIP steel specimen were not included because no additional peaks were revealed, also showing four peaks for $\mathrm{Fe} 2 \mathrm{p}_{3 / 2}$, and two peaks for $\mathrm{Al} 2 \mathrm{p}$.

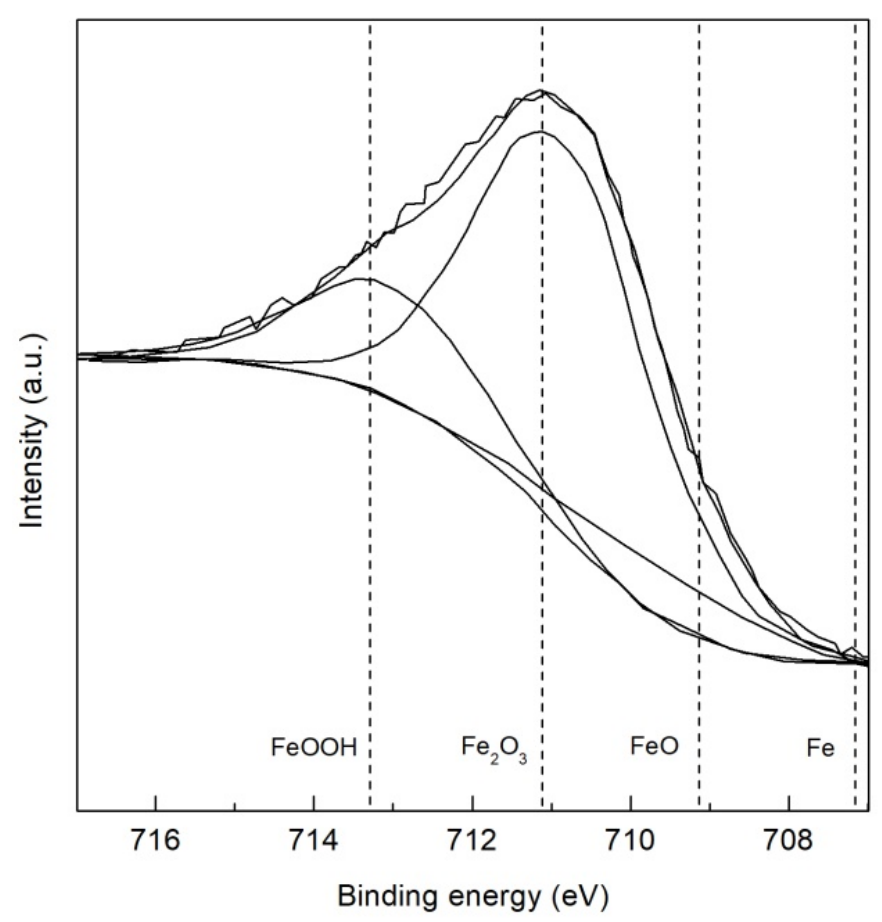

Figure 6. High resolution XPS spectra for Fe $2 \mathrm{p}_{3 / 2}$ of TMP TWIP steel.

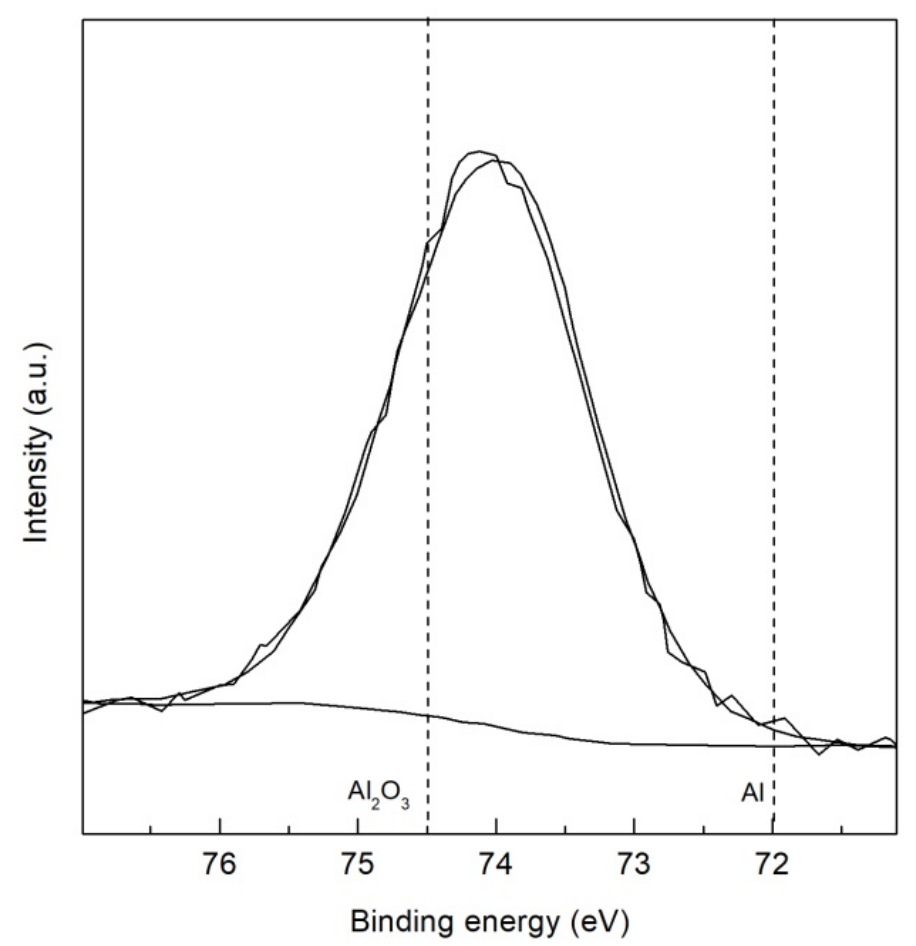

Figure 7. High resolution XPS spectra for Al 2p of TMP TWIP steel. 
A small peak was observed for Mn in both the TMP and recrystallized specimens. Thus, the deconvolution of the data could not be performed. Mn oxides are easily formed and dissolved preferentially at the exposed surface due to the lower stability of the Mn in the Fe-Mn based TWIP steel alloy containing $\mathrm{Al}[40]$. The atomic percentage (at.\%) of manganese analyzed was 0.5 and 0.4 at.\% Mn for TMP and recrystallized TWIP steel specimens, respectively.

The cationic fractions of $\mathrm{Fe}_{\text {cat }}, \mathrm{Al}_{\text {cat }}$, and $\mathrm{Mn}_{\text {cat }}$ for $\mathrm{Fe}, \mathrm{Al}$, and $\mathrm{Mn}$, respectively, were used to analyze the passive layer composition. The cationic fraction is determined by the relationship between a specific oxide and the addition of each contribution of the oxides that form the passive layer. For instance, the expression for $\mathrm{Al}$ would be: $\mathrm{Al}_{\mathrm{cat}}=\mathrm{Al}_{\mathrm{ox}} /\left(\mathrm{Fe}_{\mathrm{ox}}+\mathrm{Al}_{\mathrm{ox}}+\mathrm{Mn}_{\mathrm{ox}}\right)$, where $\mathrm{Fe}_{\mathrm{ox}}$, $\mathrm{Al}_{\mathrm{ox}}$, and $\mathrm{Mn}_{\mathrm{ox}}$ are the oxides of $\mathrm{Fe}, \mathrm{Al}$, and $\mathrm{Mn}$, respectively.

The cationic fractions for $\mathrm{Fe}, \mathrm{Al}$, and $\mathrm{Mn}$ elements for the TMP specimen were determined to be: $0.43,0.49$, and 0.08 for $\mathrm{Al}, \mathrm{Fe}$, and $\mathrm{Mn}$, respectively. For the recrystallized TWIP steel specimen the cationic fractions were: $0.06,0.91$, and 0.03 for $\mathrm{Fe}, \mathrm{Al}$, and $\mathrm{Mn}$, respectively. The passive layer of both the TMP and recrystallized TWIP steels is mainly composed of Fe and Al oxides. The content of the $\mathrm{Al}_{2} \mathrm{O}_{3}$ in the passive layer increased up to $91 \%$ for the recrystallized TWIP, compared with $43 \%$ for TMP specimen. As indicated above, the passivating properties of $\mathrm{Al}$ alloying element are higher than Fe and Mn [26,31,41]. These results agree with the information supplied by Pourbaix diagram indicating that $\mathrm{Al}$ generates a protective and stable $\mathrm{Al}_{2} \mathrm{O}_{3}$ layer in the $\mathrm{pH}$ range of 4-9 [42]. Therefore, this corroborates the electrochemical CPP results obtained in the present study.

A significant difference in the Gibbs free energy $\left(G_{298}\right)$ at room temperature of the different oxides determines which element will be preferentially oxidized. In this case, the $G_{298}$ for the different oxides are: $\mathrm{Al}_{2} \mathrm{O}_{3}(-1582.4 \mathrm{~kJ} / \mathrm{mol}), \mathrm{Fe}_{2} \mathrm{O}_{3}(-742.0 \mathrm{~kJ} / \mathrm{mol}), \mathrm{Fe}_{3} \mathrm{O}_{4}(-1015.5 \mathrm{~kJ} / \mathrm{mol}), \mathrm{Mn}_{2} \mathrm{O}_{3}(-881.1 \mathrm{~kJ} / \mathrm{mol})$, and $\mathrm{Mn}_{3} \mathrm{O}_{4}(-1283.2 \mathrm{~kJ} / \mathrm{mol})$. This indicates that an $\mathrm{Al}_{2} \mathrm{O}_{3}$ enriched surface oxide layer may be present due to the preferential oxidation of $\mathrm{Al}[40,43]$. Interestingly, despite this enrichment of $\mathrm{Al}^{3+}$ ions within the oxide layer, other ions were also found in large quantities $\left(\mathrm{Fe}^{2+}, \mathrm{Fe}^{3+}, \mathrm{Mn}^{2+}\right.$ and $\left.\mathrm{Mn}^{3+}\right)$, indicating that the passive layer should be considered as a mixture of $\mathrm{Fe}, \mathrm{Al}$ and $\mathrm{Mn}$ oxides.

\section{Conclusions}

Recrystallized TWIP steel specimens showed homogeneous monophasic austenite microstructure consisting of equiaxial grains with the presence of recrystallization twins. On the TMP TWIP steel specimens, the hot-rolling process generated oriented grains with zones including grain boundary sliding and dislocations glide.

Electrochemical measurements indicated that the TMP TWIP steel presented lower corrosion resistance than the recrystallized specimens. The stability of the passive layer is lower for TMP specimens than for recrystallized specimens, due to the thermo-mechanical processing (TMP) which introduces discontinuities in the alloy matrix. The beneficial effect of $\mathrm{Al}$ was also observed on the TWIP steel, promoting a protective passive layer. In general, the hysteresis loop that was defined in the CPP curves decreases for the TMP TWIP steel. Furthermore, an improved corrosion resistance is observed for the recrystallized specimens compared to the TMP TWIP steel.

The pit density decreased with the recrystallization process, as seen from the IFM results, being in good agreement with the CPP analysis. Nevertheless, the pit depth was kept constant at $6 \mu \mathrm{m}$ for both the TMP and the recrystallized TWIP steel specimens.

XPS analysis for both specimens showed that their passive layers were mainly composed by Fe and $\mathrm{Al}$ oxides, metallic $\mathrm{Al}$, and bound water. A small peak of Mn oxide and hydroxide has also been detected.

Author Contributions: Conceptualization, D.M.B.; methodology, U.M., J.R., J.B. and D.M.B.; formal analysis, U.M., J.R., J.B. and D.M.B.; investigation, U.M., J.R., J.B. and D.M.B.; resources, D.M.B.; data curation, U.M., J.R., J.B. and D.M.B.; writing-original draft preparation, U.M., J.R., J.B. and D.M.B.; writing-review and editing, U.M., J.R., J.B. and D.M.B.; visualization, D.M.B.; supervision, D.M.B.; project administration, D.M.B.; funding acquisition, D.M.B. All authors have read and agreed to the published version of the manuscript. 
Funding: This research was funded by Firestone Research, grant number 639430 and The University of Akron.

Acknowledgments: The authors acknowledge the technical support and facilities from The National Center for Education and Research on Corrosion and Materials Performance (NCERCMAP-UA), The College of Engineering and Polymer Science and The University of Akron.

Conflicts of Interest: The authors declare no conflict of interest.

\section{References}

1. Cornette, D.; Galtier, A. Influence of the forming process on crash and fatigue performance of high strength steel automotive components. In Proceedings of the Technical Paper of the SAE World Congress; SAE International: Detroit, MI, USA, 2002.

2. Thorpe, M.D.; Adam, H. ULSAB-AVC overview and design (ultralight steel auto body-Advanced vehicle concepts). In Proceedings of the Technical Paper of the SAE World Congress; SAE International: Detroit, MI, USA, 2002.

3. Allain, S.; Chateau, J.P.; Bouaziz, O. A physical model of the twinning-induced plasticity effect in a high manganese austenitic steel. Mater. Sci. Eng. A 2004, 387-389, 143-147. [CrossRef]

4. Pierce, D.T.; Jiménez, J.A.; Bentley, J.; Raabe, D.; Wittig, J.E. The influence of stacking fault energy on the microstructural and strain-hardening evolution of Fe-Mn-Al-Si steels during tensile deformation. Acta Mater. 2015, 100, 178-190. [CrossRef]

5. Tuan, Y.H.; Wang, C.S.; Tsai, C.Y.; Chao, C.G.; Liu, T.F. Corrosion behaviors of austenitic Fe-30Mn-7Al-xCr-1C alloys in 3.5\% NaCl solution. Mater. Chem. Phys. 2009, 114, 595-598. [CrossRef]

6. Grässel, O.; Krüger, L.; Frommeyer, G.; Meyer, L. High strength Fe-Mn-(Al, Si) TRIP/TWIP steels development-Properties-Application. Int. J. Plast. 2000, 16, 1391-1409. [CrossRef]

7. Bouaziz, O.; Allain, S.; Scott, C. Effect of grain and twin boundaries on the hardening mechanisms of twinning-induced plasticity steels. Scr. Mater. 2008, 58, 484-487. [CrossRef]

8. De Cooman, B.; Chin, K.; Kim, J.K. High Mn TWIP steels for automotive applications. In New Trends and Developments in Automotive System Engineering; IntechOpen Ltd: London, UK, 2011; ISBN 9789533075174.

9. Sato, K.; Tanaka, K.; Inoue, Y. Determination of the $\alpha / \gamma$ equilibrium in the iron rich portion of the Fe-Mn-Al system. ISIJ Int. 1989, 29, 788-792. [CrossRef]

10. Sugimoto, K.; Kikuchi, R.; Hashimoto, S. Development of high strength low alloy TRIP-aided steels with annealed martensite matrix. Steel Res. 2002, 73, 253-258. [CrossRef]

11. Soulami, A.; Choi, K.S.; Shen, Y.; Liu, W.N.; Sun, X.; Khaleel, M.A. On deformation twinning in a $17.5 \%$ Mn-TWIP steel: A physically based phenomenological model. Mater. Sci. Eng. A 2011, 528. [CrossRef]

12. Allain, S.; Chateau-Cornu, J.P.; Bouaziz, O.; Migot, S.; Guelton, N. Correlations between the calculated stacking fault energy and the plasticity mechanisms in Fe-Mn-C alloys. Mater. Sci. Eng. A 2004, 387-389, 158-162. [CrossRef]

13. Remy, L. Temperature variation of the intrinsic stacking fault energy of a high manganese austenitic steel. Acta Metall. 1977, 25, 173-179. [CrossRef]

14. Chen, S.; Rana, R.; Haldar, A.; Ray, R.K. Current state of Fe-Mn-Al-C low density steels. Prog. Mater. Sci. 2017, 89, 345-391. [CrossRef]

15. Jacob, R.; Raman Sankaranarayanan, S.; Kumaresh Babu, S.P. Recent advancements in manganese steels-A review. Mater. Today Proc. 2020, 27, 2852-2858. [CrossRef]

16. Dieudonné, T.; Marchetti, L.; Wery, M.; Miserque, F.; Tabarant, M.; Chêne, J.; Allely, C.; Cugy, P.; Scott, C.P. Role of copper and aluminum on the corrosion behavior of austenitic Fe-Mn-C TWIP steels in aqueous solutions and the related hydrogen absorption. Corros. Sci. 2014, 83, 234-244. [CrossRef]

17. Bouaziz, O.; Allain, S.; Scott, C.P.; Cugy, P.; Barbier, D. High manganese austenitic twinning induced plasticity steels: A review of the microstructure properties relationships. Curr. Opin. Solid State Mater. Sci. 2011, 15, 141-168. [CrossRef]

18. Gutierrez-Urrutia, I.; Zaefferer, S.; Raabe, D. The effect of grain size and grain orientation on deformation twinning in a Fe-22 wt.\% Mn-0.6 wt.\% C TWIP steel. Mater. Sci. Eng. A 2010, 527, 3552-3560. [CrossRef]

19. Frommeyer, G.; Brüx, U.; Neumann, P. Supra-ductile and high-strength manganese-TRIP/TWIP steels for high energy absorption purposes. ISIJ Int. 2003, 43, 438-446. [CrossRef] 
20. Hamada, A.S.; Karjalainen, L.P.; El-Zeky, M.A. Effect of anodic passivation on the corrosion behaviour of Fe-Mn-Al steels in 3.5\% NaCl. In Passivation of Metals and Semiconductors, and Properties of Thin Oxide Layers; Marcus, P., Maurice, V., Eds.; Elsevier: Amsterdam, The Netherlands, 2006; pp. 77-82. ISBN 9780444522245.

21. Bastidas, D.M.; Ress, J.; Martin, U.; Bosch, J. Corrosion mechanisms of high-Mn twinning-induced plasticity steels: A critical review. Unpublished work.

22. Bosch, J.; Martin, U.; Aperador, W.; Bastidas, J.M.; Ress, J.; Bastidas, D.M. Corrosion behaviour of high-Mn austenitic Fe-Mn-Al-Cr-C TWIP steels in $\mathrm{NaCl}$ and $\mathrm{NaOH}$ solutions. Unpublished work.

23. Grajcar, A. Corrosion resistance of high-Mn austenitic steels for the automotive industry. In Corrosion Resistance; InTech: Rijeka, Croatia, 2012; Chapter 16; pp. 356-376. [CrossRef]

24. Ghayad, I.; Hamada, A.S.; Girgis, N.N. Effect of cold working on the aging and corrosion behavior of Fe-Mn-Al stainless steel. In Proceedings of the EUROCORR 2004 Conference, Nice, France, 12-16 September 2004.

25. Kannan, M.B.; Raman, R.K.S.; Khoddam, S.; Liyanaarachchi, S. Corrosion behavior of twinning-induced plasticity (TWIP) steel. Mater. Corros. 2013, 64, 231-235. [CrossRef]

26. Zhang, Y.; Zhu, X. Electrochemical polarization and passive film analysis of austenitic Fe-Mn-Al steels in aqueous solutions. Corros. Sci. 1999, 41, 1817-1833. [CrossRef]

27. Hamada, A.S.; Karjalainen, L.P. Corrosion behaviour of high-Mn TWIP steels with electroless Ni-P coating. Open Corros. J. 2010, 3, 1-6. [CrossRef]

28. Fajardo, S.; Llorente, I.; Jiménez, J.A.; Bastidas, J.M.; Bastidas, D.M. Effect of Mn additions on the corrosion behaviour of TWIP Fe-Mn-Al-Si austenitic steel in chloride solution. Corros. Sci. 2019, 154, 246-253. [CrossRef]

29. Monrrabal, G.; Jiménez, J.A.; Ress, J.; Fajardo, S.; Bastidas, J.M.; Llorente, I.; Bastidas, D.M. Corrosion behaviour of resistance-spot-welded high-Mn austenitic TWIP steel. Corros. Eng. Sci. Technol. 2020, 1-10. [CrossRef]

30. Bagotsky, V.S. Fundamentals of Electrochemistry; John Wiley \& Sons, Inc.: Hoboken, NJ, USA, 2005; ISBN 9780471741992.

31. Hamada, A.S.; Karjalainen, L.P. Nitric acid resistance of new type Fe-Mn-Al stainless steels. Can. Metall. Q. 2006, 45, 41-48. [CrossRef]

32. Zhu, X.M.; Zhang, Y.S. Investigation of the electrochemical corrosion behavior and passive film for Fe-Mn, Fe-Mn-Al, and Fe-Mn-Al-Cr alloys in aqueous solutions. Corrosion 1998, 54, 3-12. [CrossRef]

33. ASTM G61-86(2018) Standard Test Method for Conducting Cyclic Potentiodynamic Polarization Measurements for Localized Corrosion Susceptibility of Iron-, Nickel-, or Cobalt-Based Alloys; ASTM International: West Conshohocken, PA, USA, 2018.

34. Bastidas, J.M.; López, M.F.; Gutiérrez, A.; Torres, C.L. Chemical analysis of passive films on type AISI 304 stainless steel using soft X-ray absorption spectroscopy. Corros. Sci. 1998, 40, 431-438. [CrossRef]

35. Gwon, H.; Kim, J.K.; Jian, B.; Mohrbacher, H.; Song, T.; Kim, S.K.; De Cooman, B.C. Partially-recrystallized, $\mathrm{Nb}$-alloyed TWIP steels with a superior strength-ductility balance. Mater. Sci. Eng. A 2018, 711, 130-139. [CrossRef]

36. Berrenberg, F.; Haase, C.; Barrales-Mora, L.A.; Molodov, D.A. Enhancement of the strength-ductility combination of twinning-induced/transformation-induced plasticity steels by reversion annealing. Mater. Sci. Eng. A 2017, 681, 56-64. [CrossRef]

37. Charles, J.; Berghezan, A.; Lutts, A. Structure and mechanical properties of high-alloy manganese-aluminum steels for cryogenic applications. In Austenitic Steels at Low Temperatures; Reed, R.P., Horiuchi, T., Eds.; Springer: Boston, MA, USA, 1983; pp. 311-326. ISBN 9781461337300.

38. Ghods, P.; Isgor, O.B.; Brown, J.R.; Bensebaa, F.; Kingston, D. XPS depth profiling study on the passive oxide film of carbon steel in saturated calcium hydroxide solution and the effect of chloride on the film properties. Appl. Surf. Sci. 2011, 257, 4669-4677. [CrossRef]

39. López, M.; Gutiérrez, A.; Torres, C.; Bastidas, J. Soft x-ray absorption spectroscopy study of electrochemically formed passive layers on AISI 304 and 316L stainless steels. J. Mater. Res. 1999, 14, 763-770. [CrossRef]

40. Zhang, Y.; Zhu, X.; Liu, M.; Che, R. Effects of anodic passivation on the constitution, stability and resistance to corrosion of passive film formed on an Fe-24Mn-4Al-5Cr alloy. Appl. Surf. Sci. 2004, 222, 89-101. [CrossRef]

41. Lins, V.F.C.; Freitas, M.A.; Silva, E.M.P. Corrosion resistance study of Fe-Mn-Al-C alloys using immersion and potentiostatic tests. Appl. Surf. Sci. 2005, 250, 124-134. [CrossRef] 
42. Deltombe, E.C.; Vanleugenhagle, M.; Pourbaix, M. Atlas of Electrochemical Equilibria in Aqueous Solution; Elsevier: Oxford, UK, 1966; ISBN 0915567989.

43. Roberge, P.R. Handbook of Corrosion Engineering, 2nd ed.; McGraw-Hill Education: New York, NY, USA, 2012; ISBN 9780071750370.

Publisher's Note: MDPI stays neutral with regard to jurisdictional claims in published maps and institutional affiliations.

(C) 2020 by the authors. Licensee MDPI, Basel, Switzerland. This article is an open access article distributed under the terms and conditions of the Creative Commons Attribution (CC BY) license (http://creativecommons.org/licenses/by/4.0/). 